\title{
Actors' Influences on Land Use Planning Decisions in Small Towns: The Case of Geita, Gairo and Kibiti Towns in Tanzania
}

\author{
Ally H. Namangaya, Dawah M. Mushi \\ School of Spatial Planning and Social Sciences, Ardhi University, Dar es Salaam, Tanzania \\ Email: namangaya@yahoo.com, dimushi2000@yahoo.com
}

How to cite this paper: Namangaya, A.H. and Mushi, D.M. (2019) Actors' Influences on Land Use Planning Decisions in Small Towns: The Case of Geita, Gairo and Kibiti Towns in Tanzania. Open Journal of Social Sciences, 7, 172-190.

https://doi.org/10.4236/jss.2019.77016

Received: June 10, 2019

Accepted: July 21, 2019

Published: July 24, 2019

Copyright (๑) 2019 by author(s) and Scientific Research Publishing Inc. This work is licensed under the Creative Commons Attribution International License (CC BY 4.0).

http://creativecommons.org/licenses/by/4.0/

\begin{abstract}
Towards the turn of the century, Tanzania, like many countries in Africa adopted urban planning approaches that targeted a wider stakeholders' engagement through the use of communicative platforms and inclusive structures for decision making in the planning processes. These approaches are being practised in large and small urban centres, although most of piloting for the efficacy of such approaches was done in large urban centres. However, after over twenty years of these practices, the achievements have been less than optimal with many plans not being implemented. The proliferation of informality and poorly managed small urban centres continue to emerge and grow unabated. This paper examines the planning process in three small urban centres to uncover the level of conformity between applications of the participatory and commutative approaches, and the interests and actions of stakeholders in the planning process. It comes out that although normatively the procedures and institutional structure have adopted the requirements of participatory and communicative planning, the practice has managed to resist the openness and comprehensive inclusions of all stakes in the process. As a result, there is continued discord between the envisaged nature and content of the plans and the motives and demands of those with a stake in the small towns' development endeavours, which contribute to the unwillingness of the developers to heed to the proposals of the plans. It is important therefore not to concentrate on the procedural requirements in the planning process but to improve inclusion of stakes and to focus on honest mediation of self-interests in the planning processes.
\end{abstract}

\section{Keywords}

Urban Planning, Land Use Planning, Small Towns 


\section{Background}

As the whole world is increasingly urbanized, Sub-Saharan Africa will be among the regions that will register the fastest rate of urbanisation for the next four decades, where, it is estimated that almost two-thirds of the population growth is expected to be urban by 2050 [1]. Most of the urban growth will occur in the Global South in market towns and administrative centres of between 5000 and 100,000 inhabitants [2]. However, there have been very low infrastructure investments and policy neglect in small towns despite their burgeoning population [3]. To broadly define small towns in literature, there is a wide range of population sizes considered for small towns, ranging generally between above 10,000 and below 100,000 people, but many of these scholars have put the upper limit in population size to be 50,000 people [4] [5] [6]. In Tanzania, the classification as "small towns" does not exist, instead there is a class of minor towns with populations ranging between 10,000 and 30,000, and towns which are considered to have population ranging between 30,000 and 100,000 people, although in most of scholarly and policy discussions the two classes are considered to be in a category of small towns [7].

Despite their increasing dominance in urbanisations landscape, small towns have suffered neglect, where in Europe, metropolises were desired centres of consumerism and small towns were left to meet natural death [8] [9]. In the African context the neglect has been there too, until the need to stem rural-urban migration and avoid the decline of rural towns has regenerated research interests in small town research [10] [11]. Many of the African studies on small towns focus on local development, economic growth and businesses in small towns [11]-[16]. In Tanzania, the Tanzanian National Audit Office 2014 Report [17], has reported that the challenge is not only that $80 \%$ of the towns do not have spatial plans, but even those with plans are never implemented. The same situation is widely reported by other studies in Tanzania and beyond [18] [19].

\section{Urban Planning in Small Towns}

From early 1990s, urban planning practices have moved into the institutionalisation of communicative form of planning as a way of creating census and therefore manning better development in urban areas, as result appreciating the complexity (wickedness) of urban planning issues [20] [21] [22] [23]. Others call such processes creation of a conducive-milieu for collective action, or community development action planning, where there is a partnership between public, private and sub-national/local state organs, and adopt the use of endogenous and territorial advantages as well as use of power of information sharing, databases and media [24] [25] [26]. This specific form of participatory planning is said to promote shared ambition, perception, understanding and responsibility and a move towards sustainability [27] [28]. Of critical importance in small towns is encountering sprawl, reduce the environmental impact of these towns 
and promote compact development [29] and engendering human scale development [30] [31].

The motivations for actors to commit and engage effectively in this form of planning is to protect their stake, which is defined either by the mandates entrusted on them by the general public or/and self-interests aiming at benefiting or avoiding loss [32]. The central role of mandated institutions is to provide constraints to the actions (through rules and regulations), and adequate and equal amount of information so that the decisions and actions undertaken by self-interested individuals are based on sound knowledge. Hence, mandated institutions work in the realm of fostering instrumental rationality [33]. However, in the scale of small towns or any detailed level planning, where actors have a better knowledge of each other and are bound not only by formal constraints but also informal knowledge of each other and social norms, the choice of decisions is dominantly shaped by the communicative rationalities [34] [35].

Tanzania has also been attempting to institutionalise communicative planning in various cases of planning practice [18] [36]-[41], yet the results have been generally very low level of plan implementations effectiveness of the resultant plans [17] [42] [43]. It is of research interest to find out why few plans are prepared in small towns and when they are prepared why are they not implemented? Therefore, the specific questions that the paper attempts to respond to are: What is the nature of plans effectively demanded by actors in small towns? What are the motivations for different actors in the planning process? How are the legally stipulated procedural requirements to engage actors in the planning process conform to the constellation of self-interests in the process?

\section{Methodology}

Methodologically this paper follows action research by following and engaging in land use planning process in three small towns in Tanzania. The action research approach was adopted following grounded theory [44] where issues on the context are explored free from hypothesizing or framing from the theoretical prepositions. The idea was to facilitate the unearthing of powers and relationships in land use decisions. Noting that there is a wider discourse on merits of action research as a method of scientific inquiry [45] [46] [47], the study adopted a continuous cognisance and separation of research interests from problem-solving interests. In the data collection this was accomplished by assigning the research team for reporting (documenting actions, arguments and compositions in decision-making fora) while responsible actors continued to engage in the actual planning tasks. The documented information was supplemented by interviewing actors who either participated in the process or had a notable stake in the decisions made, including landowners, utility agencies and business communities. These actors were subjected to mini-meetings and interviews to get their insights on land governance and their contribution to the planning processes. Furthermore, literature reviews informed pertinent scholarly and context issues within the studied towns. 
The case towns are Kibiti in Rufiji District located in the Coast Region, Gairo in Gairo District is found in Morogoro Region and Geita in the Geita Region (Figure 1). Kibiti is situated about $150 \mathrm{~km}$ away from Dar es Salaam; it is a small town which was part of settlements under Rufiji District, and as a small town was a composed of three wards with a total population of about 45,000 people (2012 Tanzania Census report). At the time of planning, Kibiti had no legal autonomy and was managed under the Rufiji District Council. Rufiji District is one of the seven districts in the Coast Region. The headquarters of Rufiji District is situated about $70 \mathrm{~km}$ away in Utete Town. It was a fast growing small town along newly constructed highway from Dar es Salaam to south-eastern regions of Tanzania. In the town the informality was rapidly growing and signs of environmental degradation were eminent as manifested by frequent floods, cholera epidemics and scarcity of water during dry seasons. In 2012 Ardhi University, where authors are employed, was approached by WaterAid, a British non-governmental organisation operating worldwide, to partner with in water and sanitation impricement, whose interest was to pilot community provision of water, sanitation and health (WASH) services that would reduce capital and operating costs of the services. WASH services basically included potable water, solid waste, liquid waste and water resource conservation. The land use-planning role was to facilitate designations of land for amenities and infrastructure way-leaves. The direct costs of the planning process were paid by WaterAid, and the project ended in 2015.

Gairo was the second small town, situated in a mid-point between Morogoro and Dodoma Capital City along Morogoro-Dodoma highway. It is the headquarters of Gairo District. In 2012 Gairo settlement had the population of 52,578 people. It is located about $120 \mathrm{~km}$ from Dodoma City. In this year it was still under a rural district council, managed by a Town Executive Officer (TEO), who was an appointee of the District Executive Director (DED). The objective of the planning exercise was to issue title deeds to landowners through town-wide regularisations of settlements, which includes designating areas of amenities and infrastructure way-leaves. The planning process was funded by the landowners whose land lots had to be regularised, through a standard pay of Tshs 150,000 per lot, which is less than $1500 \mathrm{~m}^{2}$. The project took place between 2016 and 2018.

Geita, the third town, is the headquarters of Geita Region with its town council status gazetted in 2012. The town had been small until 2012 when there was the expansion of urban boundaries, the population of the primary wards before the expansion was 99,795 people. The town serves as the administrative, social and economic centre for Geita Region. The preparation of the plan was a part of fulfilling the conditions to qualify to receive the World Bank support under the Urban Local Government Support Programme (ULGSP). The ULGSP programme funded the constructions of roads, abattoir, markets and promoted own source revenue collections. The payment of the planning costs was by over half contributed by Geita Gold Mine Company which is a subsidiary of a worldwide 


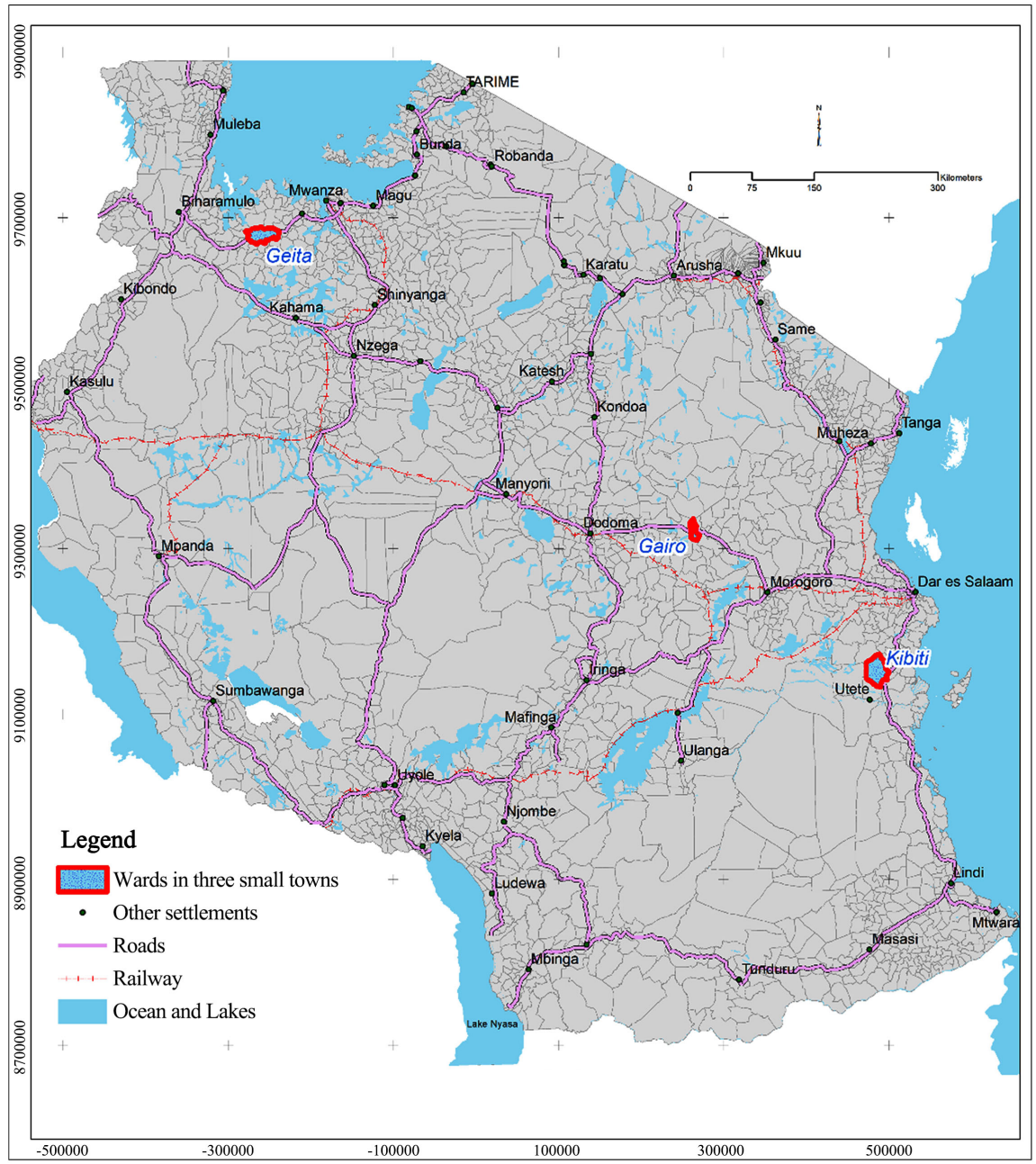

Figure 1. Location of Geita, Gairo and Kibiti towns. Source: Processing Tanzanian ward maps.

mining conglomerate, AngloGold Ashanti Limited, which is operating a gold mine in the town. The project took place between 2015 and 2018.

A general context of planning at this juncture is imperative to facilitate the understanding of the results. The institutional setup of planning in Tanzania is governed by the Urban Planning Act of 2007 and Guidelines for the Preparations of General Planning Schemes and Detailed Planning Schemes by the Ministry of Lands, Housing and Human Settlements Development (MLHHSD) in 2007 and several other regulations. In the organisation structure stipulated in the Urban Planning Act, there are three organs with specific mandates in the urban planning processes. The district councils, which are responsible for plans in small towns that have no councils of their own, like Kibiti and Gairo; urban local authorities in towns with own councils like Geita Town, Regional Administrative Secretary (RAS) offices which are present in every region and coordinate planning from different authorities; and finally, the directorate of urban and rural planning in the national Ministry of Lands, Housing and Human Settlements Development (MLHHSD). Two types of urban plans are stipulated in these 
documents, which are general planning schemes and detailed planning schemes. General planning scheme may be in the form of master plans of interim land use plans. Detailed plans may be in the form of new area neighbourhood plans, regularisations plans and urban renewal/redevelopment plans. The planning mandates rest with local authorities or special authorities declared by the minister in the MLHHSD. The local authorities use council meetings, composed of ward councillors and heads of departments, for the highest level of endorsement of the draft plan or recommending taking the plan forwarding to the office of the regional secretariat and ultimately to the MLHHSD for the approval. At the full council meeting representative participation takes place through the ward councillors. Responsibility of monitoring and making choices on the alternative ideas being generated in the planning process rests with the steering committees and technical committees. The two organs are composed of heads of departments and heads of sections in the council respectively. The institutions that open up for engagement of actors outside the council, like utility agencies, in the planning process are the technical sub-committee meetings. In practice, technical subcommittee meetings are rarely undertaken as these meetings are not required as evidence of participation in the approval process. So, the real influence of general public in planning process occurs during the initial stage of public hearing, this is when no data have been collected yet, and during the public deposit of the draft plan, which occurs after the draft plan has been partially accepted by the MLHHSD as the approving authority. For detailed planning schemes, there is a special committee formed by a selection of sectoral experts and a civil society member (Regulations on Constitutions and Procedures of Planning Authorities which are not Local Authorities of 2018). Planning authorities have options to engage, coordinate with and use input ideas from landowners, utility agencies and other institutions operating in the area (Regulation on Coordination and Operations with Urban Planning Authorities of 2018).

\section{Mapping of Actors and Their Interests in the Three Small Towns}

The results of the study show that in the three small towns there were a number of actors who were common in all the three small towns, regardless of the nature, purpose or kind of planning project that was undertaken. The actors of interest here are not the lumped-up planning authorities, but broken down into subgroups of actors who were considered to have specific contributions and influences in the planning process. For each actor, the nature of their engagement, interest and influence is described in the following section.

Case 1: Actors in the preparations of the general planning scheme and detailed plans in Kibiti Town

Kibiti had previously received a 0.5 billion dollars water supply scheme whose sustainability was being threatened by the legal hurdle that a settlement that is not an autonomous urban centre could not manage a water scheme. There were also issues with the poor status of sanitation services and electric supply, there- 
fore, it was the interest of WaterAid to ensure Kibiti qualifies to have an independent cluster of water supply while also facilitating provisions of other WASH services, therefore contribute in managing spatial informality. The goal was for Kibiti to grow and independently collect and manage the revenue from the water bills, and other user services fees that were being collected by the district council. It was also for Kibiti to stop the tendence by the district council of the collected revenue not to be ploughed back into serving the town. The land use planning was seen as an important starting point where growth could be managed but also justifications could be brought up for a self-managed independent urban centre. WaterAid then initiated the planning process for Kibiti town and financed direct costs in the land use planning process. In the course of the process it was logical to include detailed plans for the central area to be able to designate infrastructure way-leaves, the fact which was welcome by landowners and other actors. In over a year of preparations of general planning scheme and a mosaic of detailed plans, WaterAid closed their finance as the process dragged on along the political path because of other interests as explained hereunder.

Another group of actors were the councillors for wards forming Kibiti settlements. Their primary interests were seeing Kibiti becoming an independent town, to have a town council and to be a parliamentary constituent. They pushed the process of land use planning with a belief that it could have facilitated in expanding the boundary of the town through the allocation of land use functions that will increase populations and revenue generating activities, which would help in justifying the independence of the town. They openly differed with sector heads of department and other councillors in the full council who opposed the establishment of the council. Ultimately, an independent council, a district town and a constituent of Kibiti were established in 2015.

Heads of lands, health and revenue departments of Rufiji District, where Kibiti town was managed from, were part of the technical team within the district council, in that case, included as actors in the planning process. Their interest in the planning process was seen in opposing the moves to establish a council in Kibiti. The reason being most of the own-source revenue for the district, including servicing fee, premiums on land sales and rents are collected in Kibiti town. Therefore, if Kibiti becomes an independent council, this group of actors would have lost their main sources of funding their sector budgets. The action that they took in order to fulfill their interest was joined as members in the steering committees, which legally is required for the preparation of a general planning scheme. This would have given them leverage in managing land use and steering decisions. However, ward councillors opposed their inclusion in the committee and formulated an alternative steering committee whose secretary was a town planner who was not the head of the department. The decision was consented in the town-wide consultative meeting and by the District Executive Director. The heads vowed to block the process to which they were successful in the case of the general planning scheme as it never got approved, however many the detailed plans prepared in the process were approved and plots were sur- 
veyed and land use allocated accordingly.

Local landowners, owning pieces of land individually were not interested in the generalised land use zoning (general planning scheme) but requited detailed land use planning. As there was no compensation fund allocated to acquire areas for amenities and public services, landowners had willingly to give their land for free. The two plans, therefore, had to be undertaken more or less concurrently. Since this group was land owning, they were afraid of losing their land for other undesired land uses which could have been suggested by the general planning scheme. The group took action of agreeing to provide for free, land for amenities and infrastructure way-leaves after the mosaic of detailed plans were developed in the inner part of the town (Figure 2). Regardless of such an influence in the implementation of the plan, this group of actors was not invited in the formal consultative meetings, separate meetings had to be designed for them to air their opinion and consent. The village government as a landowner of an unused cooperative farm consented to give for free about 17 hectares for the construction of the district headquarters but refused to give about 2.4 hectares for a landfill that would serve other two settlements of similar size in Bungu and Ikwiriri.

The power utility company (TANESCO) was interested in increasing sales of power as utilisation was very much below the generations (stepped down) capacity that was found within Kibiti. Therefore, having planning interventions would increase development activities that would require more power consumptions. This actor was also interested in getting electricity way-leaves for free as it

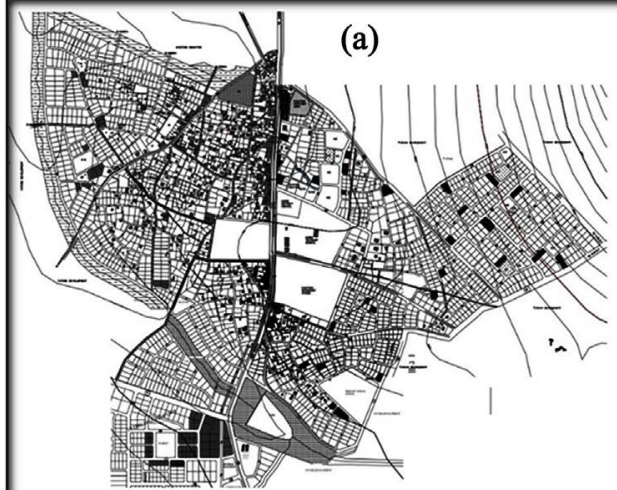

(c)

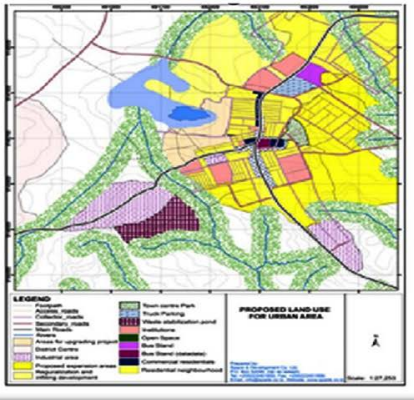

(b)

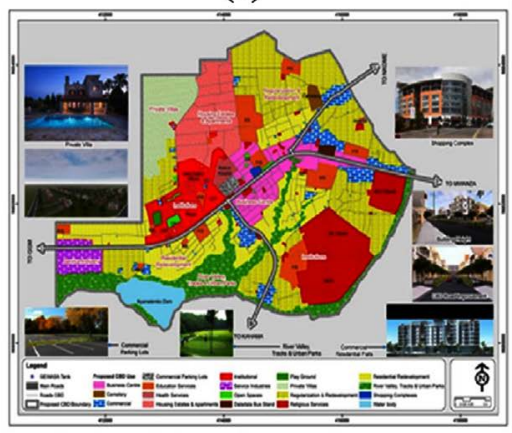

(d)

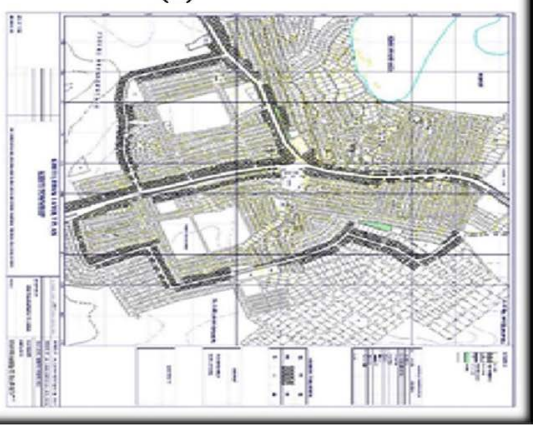

Figure 2. Final products in (a) Gairo mosaic of detailed schemes; (b) Geita central area plan; and (c) Kibiti central area plan; (d) Kibiti mosaic of detail schemes. Source: Respective planning documents. 
would be located in the plan, thus avoid compensation costs. The actions that they took in the planning process include; promised to provide power lines in areas that way-leaves were designated. They also promised to implement their power supply project for the areas whose detailed plans and survey plans were approved. The areas where the way-leaves were obtained, power supply lines were fully provided for.

Another actor who was interested in the plan and actively participated in all meetings was Rufiji Basin Development Authority (RUBADA), who had the mandate to attract investments in the Rufiji River Basin, where Kibiti was one if the central settlements. The particular interests in Kibiti were the secure land for large-scale cassava plantation which would include processing factory and a poultry farm. There were already prospective investors in these ventures but there was no land allocated for those uses. They managed to get these uses zoned but landowners required compensation, which was not paid.

Case 2: Actors in the preparations of town-wide regularisations schemes in Gairo

Actors found in Gairo Town include the constituent Member of Parliament and Gairo ward councillors whose interest in land and planning process was fulfilling the wishes of their residents by facilitating access to tenure security and therefore win people's votes and sustain their positions. The government had in 2016 announced a national wide programme to regularise informal settlements, which led to a simplification of the process and the reductions of costs of planning and surveying. The action taken by the politicians in the planning process include initiating the process by convincing the District Executive Director to recruit firms to undertake the planning and land survey activities, they monitored the process and facilitated mobilising the funds from the landowners to pay the engaged firms. Ward councillors chaired all the meetings with the community during the planning process.

Land or property owners at Gairo Town were interested in the land use planning process for the purpose of obtaining security of tenure for their land/properties as well as have access to facilities and services which usually follows after the completion of planning and land survey activities. In order to fulfill their interests, these actors had consented to give for free land for the provision of access roads and some public spaces like cemeteries; they as well subdivided their big pieces of land for privately owned public facilities (designation of plots into public uses that can be invested privately). As stated earlier, this group of actors also contributed US\$ 70 per plot as fees for detailed planning and survey. There was no attempt to prepare general planning scheme despite its importance as neither the district council nor landowners were prepared to pay for the costs. At the end of the planning process, town-wide detailed plans and survey plans were approved, where many residents obtained their certificate of right of acceptance.

Another important actor in the planning process was the Town Executive Officer (TEO) who is also an arm to the District Executive Director and is respon- 
sible for economic development and town planning activities in the small town. Legally, he is responsible for overseeing development activities in the town. In the case of Gairo, his interests were to ensure the availability and protection of areas designated for various development projects including infrastructure way-leaves and economic facilities. The TEO's contribution in the planning process was on focusing planning into detailed planning and regularization which gave government land rents and premiums as sources of own source revenue for the district council. Despite all these interests and responsibilities that the TEO had in the planning process at Gairo, he has no decision-making power on the use of own source revenue generated in the town and the patterns of service delivery.

Service delivery authorities for roads (TARURA) and power (TANESCO) were interested in the land use planning process for the purpose of getting land allocated for expanding their services and increasing customers. Neither of the two participated in the planning process since they were not invited. As it was stipulated by the Urban Planning (Cooperation and Coordination) Regulation of 2018; local authorities were mandated to cooperate with landowners and utility agents but it was not mandatory for them to do so. That is may explain why these actors were not invited or incorporated into the planning process.

Case 3: Actors in the preparations of a general planning scheme in Geita Town

One of influential actors found in Geita Town is the Geita Gold Mine (a subsidiary of AngloGold) company limited. This is the biggest global miner who contributes nearly two-thirds of total own-source revenue of the town council and funds numerous development projects. This actor's interest on the land use planning process was to discourage designation of areas for artisanal mining and mineral processing, fearing such activities could contribute to theft in the company mines. However, the company supports diversifications of the economy and employment opportunities in the town particularly towards agricultural activities. The GGM financed half of the costs in the planning process; they also wanted the plan to conform to their land rehabilitation plans. They also supported agriculture and technical education needs as part of a corporate social responsibility and a good-image building. Despite the interest and contributions this actor made, GGM was not invited by the planning authority (Geita Town Council) to the consultative meetings that commented and endorsed the prepared master plan. When the head of the urban planning department was asked of their absence, he said that they had been represented by other actors.

Church organisations (Catholic and African Inland Church of Tanzania) are two Christian denominations that are among the biggest landowners in Geita Town. Both churches own big chunks of land and are running several development projects and private social services, servicing the whole town and region in general. Their interest in the land use planning process was to maintain their land and projects through utilising the land lots in accordance with their planned projects. In the planning process they supported designations of their 
land parcels as centres for social services. Also they were not invited by the planning authority to the consultative meetings that commented and endorsed the master plan.

The Regional Secretariat Office, being the central government arm that administers the region, had interest in the land use planning process so that they continue with the management and financing agricultural irrigations and livestock keeping projects within the urban boundary. They also had an interest in continuing to manage the ongoing construction of the regional and council headquarters that was allocated in a designated forest reserve. In the planning process, they managed to ensure that government lands that had agricultural projects remained in that use despite being in the newly established urban area. They also lobbied for conversion for a part of a forest reserve in the inner part of the town into the residential and institutional area to ensure the envisaged regional and district centre remained in their preferred locations.

Utility Agencies such as that dealing with water supply (GEUWASA), power supply (TANESCO) and roads (TARURA and TANROAD), were interested in the land use planning process in Geita town for obtaining land easily and with little or no compensation costs for the expansion of their services and facilities. For example, GEUWASA was interested in the extension of water supply in the town since the town had the lowest rate of household access to potable water among the urban areas in the country. In this planning process, they had interest in getting water supply way-leaves, areas to locate reservoir tanks and protection of water sources. That was the same for power supply and road agencies, they also required way-leaves so as to reduce or avoid compensation costs and to connect the town with other places. There was no much action by these infrastructure supply agencies since they were not invited in planning meetings for endorsement, they ended up having plans which did not conform to detailed plans since they had no chance to comment or incorporating their plans with that of the master plan.

Plan International is among the international NGOs operating in Geita Town. Their interest in the land use planning process was getting support to continue with their projects on the supply of potable water for low-income households outside the grid through the construction of deep wells, as well as environmental conservations of water sources in the town. They wanted support to keep artisanal miners' activities away from forests and water sources. Regardless of their good intention to the environment conservation of the town, they were not invited by the planning authority to the consultative meetings that commented or endorsed the plan.

Small-scale miners are one of the largest groups of influential people on the land use planning process in Geita Town. Their interest was to continue with mining activities regardless of the presence of a big mining company. They expected the planning process to designate artisanal mining areas, provide the information base for the potentiality of minerals in various areas and provide areas for semi-processing and selling. Despite mining being one of the important em- 
ployment sources, small scale miners' needs did not come up in the land use plan, except for the designation of mineral processing and auctioning areas. Nevertheless, this group was not invited by the planning authority to the consultative meetings that commented or endorsed the plan.

\section{Discussion}

The first question the paper attempts to answer is the nature of plans demanded by the actors in small towns. From the three cases, the preference of local actors has been the detailed plans, which deals direct with land tenure issues. This has been the case in Kibiti where landowners demanded the detailed plans and devoted time to it. In Gairo, the need for detailed regularisation plans was locally initiated and funded. In both cases of Gairo and Kibiti, landowners agreed to part with some of the land lots for utilities way-leaves and amenities, which is the condition for getting the plan approved. In Geita it is the condition of the World Bank infrastructure funding that stimulated the need to prepare a general planning scheme, but local stakeholders believe that the town could develop without a master plan. Despite Geita being one of the councils with adequate own source revenue, the initial funding of preparations of general planning scheme had to come from Geita Gold Mine Company.

General planning schemes seem to be needed by institutional actors like WaterAid and the World Bank, while the district and town councils, as planning authorities, did not show self-motivation for this type of plan. When communities in Gairo initiated the preparations of town-wide regularisations plan, one would have expected the councils to jump into the wagon by demanding the general plan be prepared to show major land use and guide functional relationship among the detailed plans. This did not happen and the council continued to support the preparation of the mosaic of detailed plans (Matrix 1).

It is evident from this discussion that there is no effective demand for general planning scheme in small towns. This does not come as surprise since even other studies have shown that detailed plans have a higher chance of being implemented than proposals in general planning schemes [43]. The (Tanzania) Urban Planning Act of 2007 support this set up by first allowing detailed plans to be prepared even where there is no general planning scheme, and stating that when detail planning scheme has been approved it has a force of law, but not the general planning schemes. Considering the functional importance of general planning schemes in linking transportation networks and relationship among major land uses and designating for non-residential functions, their lack of prioritisation explains the dominance of residential functions in Tanzanian cities to a tune of over 90 percent [43] [48]. The argument of costs could be brought up but evidence does not support it. For example, the project costs including the preparation of a general planning scheme in Kibiti was about 100,000 US\$ in the area of $1289.9 \mathrm{~km}^{2}$ giving an average of 77 US $\$$ per $\mathrm{km}^{2}$. For Geita was 180,000 US\$ in the area on $1240 \mathrm{~km}^{2}$ giving 145 US\$ per $\mathrm{km}^{2}$. For Kibaha, another small 
Matrix 1. A summary of actors' interests and influences in the planning process.

\begin{tabular}{|c|c|c|c|c|c|c|c|c|c|c|c|c|}
\hline & $\begin{array}{l}\text { Focus on } \\
\text { detailed } \\
\text { planning } \\
\text { issues }\end{array}$ & $\begin{array}{l}\text { Focus } \\
\text { on the } \\
\text { general } \\
\text { Planning } \\
\text { scheme }\end{array}$ & $\begin{array}{l}\text { Initiate/ } \\
\text { lead } \\
\text { in the } \\
\text { planning } \\
\text { system }\end{array}$ & $\begin{array}{l}\text { Contributing } \\
\text { resources to } \\
\text { the planning } \\
\text { process }\end{array}$ & $\begin{array}{l}\text { Monitoring } \\
\text { the } \\
\text { planning } \\
\text { process }\end{array}$ & $\begin{array}{l}\text { Supportive } \\
\text { of local } \\
\text { agenda } \\
\text { in the } \\
\text { planning } \\
\text { process }\end{array}$ & $\begin{array}{l}\text { Wanting } \\
\text { to control } \\
\text { land-related } \\
\text { decisions }\end{array}$ & $\begin{array}{l}\text { Protection } \\
\text { of } \\
\text { self-interests } \\
\text { on land or } \\
\text { politically }\end{array}$ & $\begin{array}{l}\text { Involved in } \\
\text { consultative } \\
\text { and public } \\
\text { meetings }\end{array}$ & $\begin{array}{l}\text { Revenues } \\
\text { increase } \\
\text { from land } \\
\text { or space } \\
\text { use }\end{array}$ & $\begin{array}{l}\text { Continuations } \\
\text { of existing/ } \\
\text { ongoing } \\
\text { projects }\end{array}$ & $\begin{array}{l}\text { Accomplishing } \\
\text { agenda of central } \\
\text { government }\end{array}$ \\
\hline $\begin{array}{l}\text { International } \\
\text { non- } \\
\text { governmental } \\
\text { organisations } \\
\text { WaterAid, } \\
\text { Plan } \\
\text { International }\end{array}$ & $\mathrm{K}, \mathrm{Ge}$ & $\mathrm{K}$ & $\mathrm{K}$ & $\mathrm{K}$ & $\mathrm{K}$ & K & & $\mathrm{Ge}$ & $\mathrm{K}, \mathrm{Ge}$ & $\mathrm{Ge}$ & $\mathrm{K}, \mathrm{Ge}$ & $\mathrm{K}, \mathrm{Ge}$ \\
\hline $\begin{array}{l}\text { Politicians } \\
\text { including } \\
\text { ward } \\
\text { councillors, } \\
\text { members of } \\
\text { parliament }\end{array}$ & $\mathrm{K}, \mathrm{Ga}$ & K & $\mathrm{K}, \mathrm{Ga}$ & $\mathrm{K}$ & $\mathrm{K}, \mathrm{Ga}$ & $\mathrm{K}, \mathrm{Ga}$ & $\mathrm{K}, \mathrm{Ga}$ & $\mathrm{K}, \mathrm{Ga}$ & $\mathrm{K}, \mathrm{Ga}$ & $\mathrm{K}, \mathrm{Ga}$ & $\mathrm{K}, \mathrm{Ga}$ & $\mathrm{Ga}$ \\
\hline $\begin{array}{l}\text { Heads of for } \\
\text { revenue, land } \\
\text { and health } \\
\text { departments, } \\
\text { and town } \\
\text { executive } \\
\text { director, } \\
\text { and office } \\
\text { of regional } \\
\text { administrative } \\
\text { secretary }\end{array}$ & $\mathrm{K}, \mathrm{Ge}, \mathrm{Ga}$ & $\mathrm{K}, \mathrm{Ge}$ & $\mathrm{Ge}, \mathrm{Ga}$ & $\mathrm{Ga}$ & $\mathrm{K}, \mathrm{Ge}, \mathrm{Ga}$ & $\mathrm{Ga}$ & $\mathrm{K}, \mathrm{Ge}, \mathrm{Ga}$ & $\mathrm{Ge}, \mathrm{Ga}$ & $\mathrm{K}, \mathrm{Ge}, \mathrm{Ga}$ & $\mathrm{K}, \mathrm{Ga}$ & $\mathrm{K}, \mathrm{Ge}, \mathrm{Ga}$ & $\mathrm{K}, \mathrm{Ge}, \mathrm{Ga}$ \\
\hline $\begin{array}{l}\text { Land/property } \\
\text { owners } \\
\text { including } \\
\text { churches }\end{array}$ & $\mathrm{K}, \mathrm{Ge}, \mathrm{Ga}$ & $\mathrm{Ge}$ & & $\mathrm{K}, \mathrm{Ga}$ & $\mathrm{K}, \mathrm{Ga}$ & $\mathrm{K}, \mathrm{Ge}, \mathrm{Ga}$ & $\mathrm{K}$ & $\mathrm{K}, \mathrm{Ge}, \mathrm{Ga}$ & $\mathrm{K}, \mathrm{Ga}$ & $\mathrm{K}, \mathrm{Ge}, \mathrm{Ga}$ & $\mathrm{K}, \mathrm{Ge}, \mathrm{Ga}$ & $\mathrm{Ga}$ \\
\hline $\begin{array}{l}\text { Utility agents } \\
\text { (power and } \\
\text { Water supply } \\
\text { authorities, } \\
\text { road agencies) }\end{array}$ & $\mathrm{K}, \mathrm{Ge}, \mathrm{Ga}$ & & & & $\mathrm{K}, \mathrm{Ga}$ & $\mathrm{K}, \mathrm{Ga}$ & & $\mathrm{Ge}, \mathrm{Ga}$ & $\mathrm{K}$ & $\mathrm{K}, \mathrm{Ge}, \mathrm{Ga}$ & $\mathrm{K}, \mathrm{Ge}, \mathrm{Ga}$ & $\mathrm{K}, \mathrm{Ge}, \mathrm{Ga}$ \\
\hline $\begin{array}{l}\text { Business } \\
\text { community } \\
\text { including } \\
\text { Rufiji } \\
\text { Basin } \\
\text { Authority, } \\
\text { Geita Gold } \\
\text { Mine, } \\
\text { artisanal } \\
\text { miners }\end{array}$ & $\mathrm{K}, \mathrm{Ge}$ & $\mathrm{K}, \mathrm{Ge}$ & & $\mathrm{Ge}$ & & $\mathrm{K}$ & & $\mathrm{K}, \mathrm{Ge}$ & $\mathrm{K}$ & $\mathrm{K}$ & $\mathrm{Ge}$ & $\mathrm{K}$ \\
\hline
\end{tabular}

Key: The symbolic alphabets "K” stands Kibiti, "Ge" for Geita and “Ga” for Gairo. Symbols indicate interests and actions they subscribe to.

town, the costs for preparations of a general planning scheme completed in 2017 was 75,000 US\$ for an area of $750 \mathrm{~km}^{2}$ giving an average of 100 US\$ per $\mathrm{km}^{2}$. Detailed plans' standard costs range between 2500 and 5000 US\$ per $\mathrm{km}^{2}$. Definitely, it is not the actual costs of the plan preparation that makes the preference of detailed plans in small towns, but it is the utility the local actors expect from the plans.

The creative decision made in the planning process in Kibiti, where prepara- 
tion of a general planning scheme went hand in hand with detailed schemes preparation could be the way forward for small towns, also because it is practically possible. The resulting plan may not be a grand general planning scheme but a simplified scheme indicating major linkages in functions and trunk infrastructure lines and nodes. As argued by Dierwechter [49] that urban comprehensive and binding land use planning is based on the Neo-Weberian theses of state control of affairs and driving development agenda. But this needs to be in parallel with reflections of local interests as observed by Tarlock [50] in the American experience that actually the master plans if undertaken in abstract form and divorced from detailed (land tenure based) plans, the result is zoning but not real plans.

On the motivations of actors in the planning process, the protection of direct self-interest comes to the fore. This interest in landowners' need for security of tenure and preserving the uses that are commensurate with their individual plans. For planning authorities, in the case of Geita, the interest was to get funding from the World Bank funded project, for Gairo to get premiums and land rent from plot occupiers and in the case of Kibiti, the officials in the Rufiji District Council wanted to retain Kibiti as a major own source revenue collections point. Utility agents were more direct that it was the reduction of compensation costs for utility way-leaves that gets them interested in the planning process. Not so direct monetary interests could be said to be for politicians who wanted more or sustenance of local power, which of course means more resources in their disposal. For WaterAid as an NGO, the philanthropic goal could be stated that they wanted better and sustainable sanitation services for the poor residents of small towns. However, the success of the plan and therefore projects would ensure positive image for the donors. Simply put, self-interest in the forms of tangible benefits drives actors in the planning process. Therefore, the argument that planning is a set of rational actions towards generations of public goods (and control of externalities) [51] could be more direct in delivering tangible benefits to those with stake.

On the conformity of legal or institutional set up to the actual constellation of interests, it is observed that in Tanzanian context, the legal set up in the planning presupposes the rationality of the process and actors. It empowers councils' in-house actors, who are heads of sections and departments and are employees of the government posted from the central government, which means are bound to be transferred to other councils frequently. This councils' in-house group of actors forming the steering committee, and a central management team, has to make decisions on the quality of data collected, select the development strategy and influence final planning proposal in the case of a general planning scheme. Changes in 2018 of the regulations have empowered a similar committee of experts to endorse the detailed plans before getting approved at the ministerial level. Two potential problems are likely to emerge in this setup, first, the experts can craft institutional interests which may potentially defer from landowners 
and developers interests, and secondly, they may not have any interest at all in the failure or success of the plans. Disconformity of interests between the planning authority and local small town stakeholders contributed to the unsuccessful completion of general planning scheme for Kibiti, although the town stakeholders met part of their needs in the plan by having the Kibiti Settlement (as now independent district) annexed from the Rufiji District.

The representative participation through councillors in the council meetings also leaves out many critical stakeholders out of the process. The case of Geita shows that economic drivers, utility agencies and landowners can be practically left out in the planning process and yet the plan gets approved for implementation, simply because ward councillors who attended the meeting were political representatives of the people. The argument could be built that public hearing that happens before data for the plan have been collected and public deposit, which happens when the plan is awaiting final approval by the Minister, provide the room for wider direct stakeholders' engagement. But as it sounds, the former opportunity is too early to understand and comment meaningfully and the latter opportunity is almost when proposal and projects have been fully cast. This may partly explain why many plans are not implemented as landowners and utility agents have different "plans" from those provided in the formal plans. Studies have indicated that it is infrastructure development that determines the patterns of development and not mere land use proposals [52] [53] [54].

The interesting observation is, while theoretically the planning system has adopted communicative planning and created a fora and milieu for collective actions, compositions and options legally provided for government as organisers of the fora to decide whom to invite has made it possible to exclude some actors and made the interests of those in government dominate.

\section{Conclusions}

Planning is about mediating divergent self-interests among stakeholders, be it within public institutions, governmental institutions or private landowners and developers. The goals focusing on management of externalities and provision of public goods as inbuilt in the legal setup and stipulated procedures are noble but they can be manifested through interest mediation. Therefore creations of communicative planning platforms or milieu for collective actions should be cognizant of this and make sure there is an equal chance of every actor to influence the process directly. Representative participation and trust on instrumental rationality on the government actors are faulty assumptions if the goal is to make prepared plans implementable.

There is effective demand for detailed plans because they have direct tangible benefits to the individuals, which is not the case for general planning schemes. It is therefore important to develop strategies to make sure the beneficial ingredients of the general planning schemes are included in the detailed planning process. This could be done by simplifying components of the general planning 
schemes to include only those elements facilitating a better coordination of detailed planning schemes, and whenever possible make the two types of plans be undertaken in conjunction, especially in the developed part of the small towns.

\section{Conflicts of Interest}

The authors declare no conflicts of interest regarding the publication of this paper.

\section{References}

[1] United Nations Population Division (2010) World Urbanization Prospects: The 2009 Revisions. United Nations Department of Economic and Social Affairs, New York.

[2] Tacoli, C. (2004) Rural-Urban Linkages and Pro-Poor Agricultural Growth-An Overview. OECD DAC POVNET Agriculture and Pro-Poor Growth Task Team, Helsinki, 17-18 June 2004, 17-18.

[3] Caplan, K. and Harvey, E. (2010) Small Town Water and Sanitation Delivery: Taking a Wider View. WaterAid Report, WaterAid.

[4] Wisner, B., Pelling, M., Mascarenhas, A., Holloway, A., Ndong, B., Faye, P. and Simon, D. (2015) Small Cities and Towns in Africa: Insights into Adaptation Challenges and Potentials. In: Urban Vulnerability and Climate Change in Africa, Springer International Publishing, Berlin, 153-196. https://doi.org/10.1007/978-3-319-03982-4_5

[5] Raman, B. (2017) Practices of Territory in Small and Medium Cities of South India. In: Subaltern Urbanisation in India, Springer, New Delhi, 235-260. https://doi.org/10.1007/978-81-322-3616-0_9

[6] Pryadko, I. (2018) Development of Small Russian Towns in the 19th-21st Centuries: Socioeconomic Factors. MATEC Web of Conferences, 193, Article ID: 01019. https://doi.org/10.1051/matecconf/201819301019

[7] URT-United Republic of Tanzania (2000) Human Settlements Policy. Government Publisher, Dar es Salaam.

[8] Rogers, M. (2005) Social Sustainability and the Art of Engagement-The Small Towns: Big Picture Experience. Local Environment, 10, 109-124. https://doi.org/10.1080/1354983052000330734

[9] Kunzmann, K.R. (2010) Medium-Sized Towns, Strategic Planning and Creative Governance. In: Making Strategies in Spatial Planning, Springer, Berlin, 27-45. https://doi.org/10.1007/978-90-481-3106-8_2

[10] Beauchemin, C. and Schoumaker, B. (2005) Migration to Cities in Burkina Faso: Does the Level of Development in Sending Areas Matter? World Development, 33, 1129-1152. https://doi.org/10.1016/j.worlddev.2005.04.007

[11] Toerien, D.F. and Seaman, M.T. (2014) Enterprise Richness as an Important Characteristic of South African Towns. South African Journal of Science, 110, 1-9. https://doi.org/10.1590/sajs.2014/20140018

[12] Atkinson, D. (2009) Economic Decline and Gentrification in a Small Town: The Business Sector in Aberdeen, Eastern Cape. Development Southern Africa, 26, 271-288. https://doi.org/10.1080/03768350902899595

[13] Atkinson, D. (2016) Is South Africa's Great Karoo Region Becoming a Tourism Destination? Journal of Arid Environments, 127, 199-210. 
https://doi.org/10.1016/j.jaridenv.2015.12.006

[14] Donaldson, R. and Marais, L. (2012) Small Town Geographies in Africa: Experiences from South Africa and Elsewhere: 163-180. Nova Science Publishers, New York.

[15] Nel, E.L. and McQuaid, R.W. (2002) The Evolution of Local Economic Development in South Africa: The Case of Stutterheim and Social Capital. Economic Development Quarterly, 16, 60-74. https://doi.org/10.1177/0891242402016001007

[16] Binns, T. and Nel, E. (2002) Tourism as a Local Development Strategy in South Africa. Geographical Journal, 168, 235-247. https://doi.org/10.1111/1475-4959.00051

[17] URT-National Audit Office Tanzania (NOAT) (2014) Performance Audit Report on the Management of Urban Planning in Tanzania. Dar es Salaam Government Press, Dar es Salaam.

[18] Kyessi, A. (2013) Planning of Border Towns: The Case of Strategic Urban Development Plan for Tunduma Township, Mbeya Region, Tanzania. Research Workshop on Transborder Urban Networks and Urban/Regional Dynamics in Africa, Uppsala, 2-3 December 2013.

[19] Chigara, B., Magwaro-Ndiweni, L., Mudzengerere, F.H. and Ncube, A.B. (2013) An Analysis of the Effects of Piecemeal Planning on Development of Small Urban Centres in Zimbabwe: Case Study of Plumtree. International Journal of Management and Social Sciences Research, 2, 139-148.

[20] Rittel, H.W. and Webber, M.M. (1973) Planning Problems Are Wicked. Polity, 4, e169. https://doi.org/10.1007/BF01405730

[21] Healey, P., Khakee, A., Motte, A. and Needham, B. (1997) Making Strategic Spatial Plans: Innovation in Europe. UCL Press, London.

https://doi.org/10.4324/9780203451502

[22] Innes, J.E. and Booher, D.E. (2010) Planning with Complexity: An Introduction to Collaborative Rationality for Public policy. Routledge, Abingdon-on-Thames.

[23] Innes, J.E. and Booher, D.E. (2016) Collaborative Rationality as a Strategy for Working with Wicked Problems. Landscape and Urban Planning, 154, 8-10. https://doi.org/10.1016/j.landurbplan.2016.03.016

[24] Cars, G., Healey, P., Madanipour, A. and De Magalhaes, C. (2017) Urban Governance, Institutional Capacity and Social Milieux. Routledge, Abingdon-on-Thames. https://doi.org/10.4324/9781315202877

[25] Davis Jr., C.A. and Fonseca, F. (2006) Considerations from the Development of a Local Spatial Data Infrastructure. Information Technology for Development, 12, 273-290. https://doi.org/10.1002/itdj.20048

[26] Hamdi, N. (2010) The Placemaker's Guide to Building Community. Earthscan, London. https://doi.org/10.4324/9781849775175

[27] Tjallingii, S.P. (1995) Strategies for Ecologically Sound Urban Development. Ecopolis. Backhuys Publishers, Leiden, 44-53.

[28] Zlatanova, S., van Dorst, M. and Itard, L. (2007) The Role of Visual Information in Design Tools for Urban Renewal. ENHR 2007 International Conference "Sustainable Urban Areas", Rotterdam, 25-28 June 2007, 11.

[29] Ellis, C. (2002) The New Urbanism: Critiques and Rebuttals. Journal of Urban Design, 7, 261-291. https://doi.org/10.1080/1357480022000039330

[30] Max-Neef, M.A. (2005) Foundations of Transdisciplinarity. Ecological Economics, 
53, 5-16. https://doi.org/10.1016/j.ecolecon.2005.01.014

[31] Cruz, I., Stahel, A. and Max-Neef, M. (2009) Towards a Systemic Development Approach: Building on the Human-Scale Development Paradigm. Ecological Economics, 68, 2021-2030. https://doi.org/10.1016/j.ecolecon.2009.02.004

[32] Miller, D.T. (1999) The Norm of Self-Interest. American Psychologist, 54, 1053-1060. https://doi.org/10.1037/0003-066X.54.12.1053

[33] Dunn, W.N. and Miller, D.Y. (2007) A Critique of the New Public Management and the Neo-Weberian State: Advancing a Critical Theory of Administrative Reform. Public Organization Review, 7, 345-358. https://doi.org/10.1007/s11115-007-0042-3

[34] Habermas, J. and Press, P. (1989) The Public Sphere: An Inquiry into a Category of Bourgeois Society.

[35] Miller, D. (1992) Deliberative Democracy and Social Choice. Political Studies, 40, 54-67. https://doi.org/10.1111/j.1467-9248.1992.tb01812.x

[36] Halla, F. (2002) A Century of Urban Development Planning for Dar es Salaam City in and Prospects. UNCHS "Urban Poverty in Africa: Selected Countries Experiences", Nairobi, 105-113.

[37] Halla, F. (2005) Critical Elements in Sustaining Participatory Planning: Bagamoyo Strategic Urban Development Planning. Habitat International, 29, 137-161. https://doi.org/10.1016/S0197-3975(03)00077-8

[38] Halla, F. (2007) A SWOT Analysis of Strategic Urban Development Planning: The Case of Dar es Salaam. Habitat International, 31, 130-142. https://doi.org/10.1016/j.habitatint.2006.08.001

[39] Kombe, W. (2005) Institutionalising the Concept of Environmental Planning and Management: Successes and Challenges in Dar es Salaam. UN-HABITAT, Nairobi.

[40] Majani, B. (2002) Environmental Planning and Management in Dar es Salaam: A Global Success Story and Learning Experience. The Journal of Building and Land Development, 9, 67-72.

[41] Nnkya, T. and Andreason, J. (2005) Stakeholders' Involvement in the Sustainable Mwanza Programme, Tanzania. Enreca Research Report, Dar es Salaam.

[42] Namangaya, A. (2013) A Comparative Assessment of the Merits of Master Plans versus Strategic Urban Plans in Guiding Land Use Development. The Journal of Building and Land Development, 21-37.

[43] Huang, C., Namangaya, A., Weber, M. and Cantada, I. (2017) Urban Planning Study for Tanzania-Impact and Effectiveness of Urban Planning on City Spatial Development. World Bank Group, Washington DC.

[44] Glaser, B.G. and Strauss, A.L. (2017) Discovery of Grounded Theory: Strategies for Qualitative Research. Routledge, Abingdon-on-Thames.

https://doi.org/10.4324/9780203793206

[45] Davison, R., Martinsons, M.G. and Kock, N. (2004) Principles of Canonical Action Research. Information Systems Journal, 14, 65-86. https://doi.org/10.1111/j.1365-2575.2004.00162.x

[46] McKay, J. and Marshall, P. (2001) The Dual Imperatives of Action Research. Information Technology \& People, 14, 46-59. https://doi.org/10.1108/09593840110384771

[47] Butler, C. and Adamowski, J. (2015) Empowering Marginalized Communities in Water Resources Management: Addressing Inequitable Practices in Participatory Model Building. Journal of Environmental Management, 153, 153-162. 
https://doi.org/10.1016/j.jenvman.2015.02.010

[48] Lupala, J., Namangaya, A. and Mbogoro, P. (2014) Tanzania State of Cities Report. Tanzania Cities Network, Dar es Salaam.

[49] Dierwechter, Y. (2013) Smart Growth and State Territoriality. Urban Studies, 50, 2275-2292. https://doi.org/10.1177/0042098013478230

[50] Tarlock, A.D. (2014) Zoned Not Planned. Planning Theory, 13, 99-112. https://doi.org/10.1177/1473095212469942

[51] Friedmann, J. (1987) Planning in the Public Domain: From Knowledge to Action. Princeton University Press, Princeton.

[52] Namangaya, A. and Kiunsi, R. (2018) Assessing the Influences of Service Provision on Pace and Short and Medium Term Development Patterns of Residential Housing in Dar es Salaam. Geografisk Tidsskrift-Danish Journal of Geography, 118, 151-159. https://doi.org/10.1080/00167223.2018.1500490

[53] Todes, A. (2012) New Directions in Spatial Planning? Linking Strategic Spatial Planning and Infrastructure Development. Journal of Planning Education and Research, 32, 400-414. https://doi.org/10.1177/0739456X12455665

[54] Nnkya, T. (2008) Why Planning Does Not Work: Land Use Planning and Residents Rights in Tanzania. Mkukina Nyota, Dar es Salaam. 